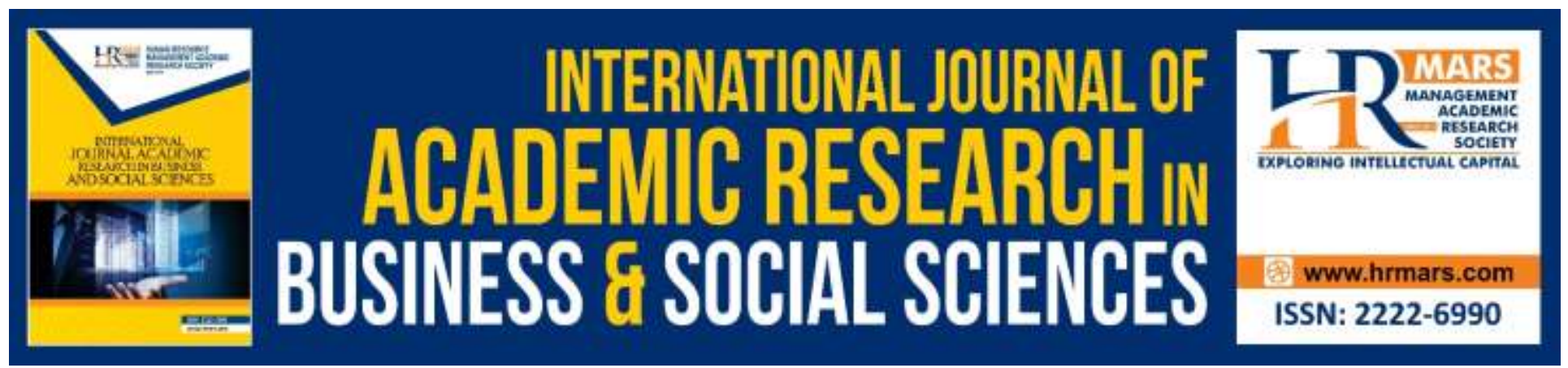

\title{
Politeness Strategies Employed by Arab EFL And Malaysian ESL Students in Making Request
}

Hussien Mohamad Alakrash, Elaf Saad Bustan

To Link this Article: http://dx.doi.org/10.6007/IJARBSS/v10-i6/7257

DOI:10.6007/IJARBSS/v10-i6/7257

Received: 02 April 2020, Revised: 05 May 2020, Accepted: 26 May 2020

Published Online: 03 June 2020

In-Text Citation: (Alakrash \& Bustan, 2020)

To Cite this Article: Alakrash, H. M., \& Bustan, E. S. (2020). Politeness Strategies Employed by Arab EFL And Malaysian ESL Students in Making Request. International Journal of Academic Research in Business and Social Sciences, 10(6), 10-20.

Copyright: @ 2020 The Author(s)

Published by Human Resource Management Academic Research Society (www.hrmars.com)

This article is published under the Creative Commons Attribution (CC BY 4.0) license. Anyone may reproduce, distribute, translate and create derivative works of this article (for both commercial and non-commercial purposes), subject to full attribution to the original publication and authors. The full terms of this license may be seen

at: http://creativecommons.org/licences/by/4.0/legalcode

Vol. 10, No. 6, 2020, Pg. 10 - 20

http://hrmars.com/index.php/pages/detail/IJARBSS

JOURNAL HOMEPAGE

Full Terms \& Conditions of access and use can be found at http://hrmars.com/index.php/pages/detail/publication-ethics 


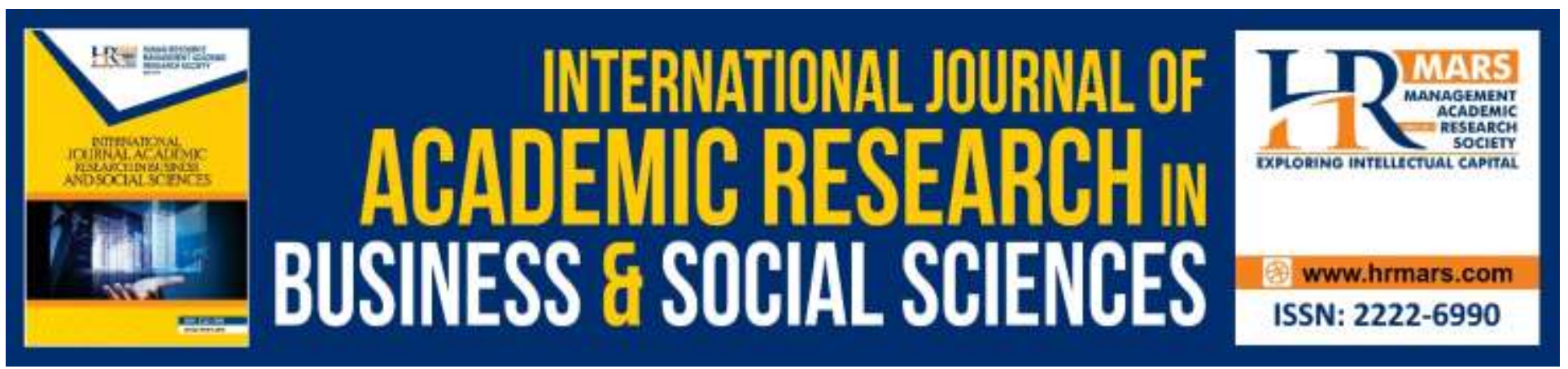

\title{
Politeness Strategies Employed by Arab EFL And Malaysian ESL Students in Making Request
}

\author{
Hussien Mohamad Alakrash, Elaf Saad Bustan \\ School of Language Studies and Linguistics, Faculty of Social Science and Humanities, Universiti \\ Kebangsaan Malaysia, Bangi, Selangor. \\ Email: Hussienalakrash94@gmail.com, elafsaad01@gmail.com
}

\begin{abstract}
In communication, speakes tend to have a polite conversation using appropriate strategies, the aim of this study is to examine the politeness strategies used by Arab and Malaysian students in making request. Also, to reveal the similarities and differences of the request strategies employed by the students. The data of the study were collected qualitatively using interview as a data collection instrument. Six post-graduate students were interviewed, three Arab and three Malay living in Malaysia. The study adopted Blum-Kulka, House, \& Kasper, (1989) as a theoretical framework to analyse the data. The results of the study showed that Malay respondents used more indirect strategies (hints, query preparatory, hedged performative). while Arabs respondents tend to use an explicit form and direct request strategies (want statements, hints). The students use of different strategies might be attributed to the different cultural backgrounds.
\end{abstract}

Keywords: Politeness Request Strategy, Speech Act Theory, Arab EFL, Malay ESL, Post-graduate Students.

\section{Introduction}

One of the most essential utilises of languages in interaction is the 'politeness strategies' use, which is likely to differ from one language to another besides from one culture to another. The emphasize of teaching in Arabic countries is one of the grammatical competence to the learners of language where the focus on grammar and phonology, then this main focus has been shifted to the pragmatic competence to draw attention to the strategies of communication. Then there was an attention to the strategies employed in communication between the same culture or cross-cultural. So far a plethora of studies has investigated the use of politeness strategies among Arab participants, across Arabic and English Tawalbeh \& Al-Oqaily, (2012). For example, Al-Qahtani (2009) examined the differences in the use of the speech act of offering as one of the politeness strategies among Saudi females in their spoken Saudi Arabic and spoken British English. Similarly, Al-Shboul, Maros, \& Yasin, (2012)compared between American English native speakers (AEL1) and Jordanian learners of English as a foreign language concerning their perceptions of advice-giving, and how it is appropriate. 
Likewise, Atawneh (1991) investigated the requesting strategies used by native speakers of Arabic and English in one hand, and Arabic-English bilinguals on the other side.

Despite various studies examined politeness strategies utilise among Arab and non-Arab respondent's, otherwise, few studies that examined or compared politeness strategies' use in English among Arab and Malay participants. Besides, both of the respondents Arab and Malay participants return from entirely different cultures. Besides, English is deemed spoken in Malaysia as a second language while it is rarely used in Arab countries in everyday life. Such a difference in language use between Arab and Malay might presume that Malay is more native-like oriented in terms of politeness strategies use than the Arab respondents. So, this research will shed light on the similarity and differences between these two diverse cultures. Therefore, there is a need to analyse politeness strategies' use between two diverse cultures, that is the Arab culture and the Malaysian culture.

Learners of English or any other target language should take into consideration the speech act of requests because they are "face-threatening acts" (FTAs) (Brown \& Levinson, 1987). People use different indirect strategies in order to save the self-image which the speaker or the hearer have and try to minimize the face threat in order to carry out the process of communication smoothly (FélixBrasdefer, 2005). Request acts might threaten the face of the speaker or the hearer if the social distance, power relations and cultural values of the others are not considered because the speech act of request is different from one culture to another (Al-Marrni et al., 2010; Tawalbeh et al., 2012; Aubed, 2012, Razak et al, 2018).

Moreover, there are many Arab EFL students who study in malaysian universities. English is the medium of instruction and the second spoken language of Malaysians, so the students intermingle as they study in same class and do group project as groups. Therefore, the aim of this study is to investigate the politeness strategies of request used by Arab EFL students and Malaysian ESL students and compare the similarities and differences the polite request strategies at public Malaysian university. In addition, few studies have investigated request strategies among Arab and Malay students, Therefore, there is a need to investigate the issue of the use of request strategies during the interaction as it helps in providing the students with the needed feedback to communicate more effectively and to improve their pragmatic competence.

\section{Literature Review}

Speech acts are often used when communicating verbally in either the first language or a second language. In other words, the most important part of pragmatics in any language consists of speech acts. Austin (1962) suggests speech acts as doing things by words such as asking, thanking, ordering, requesting, and so on. Sociolinguists recognize that such intercultural miscommunication is partly due to different value systems that underlie each first language speaker's culture group. Damen (1987) Understanding the motives behind utterances is often crucial to successful communication. Atawneh (1991) the study dealt in some detail with politeness strategies of Arabic people and British people in politeness strategies employed in the request. The study also aimed to test the politeness theory of Brown and Levinsion (1978) with Arabic-English bilinguals and Arabic monolinguals. Moreover, the analysis of the results reveals strong support for the politeness theory with regards to requests. Further, descriptive analysis suggests that Arabic has fewer modals than English and therefore, different politeness strategies are used to make up for the politeness function of modals in English. 
Umar \& Majeed (2006) the researcher conducted a socio-linguistic study to investigate the request strategies used by advanced Arab learners of English as compared to those strategies used by native speakers of English. The result of the study reveals that the two groups adopt similar strategies when addressing their request to equals or people in higher positions. Al-Marrani \& Sazalie (2010) the researcher in this study examined the notion of polite request strategies as used by female speakers of Yemeni Arabic in the same gender and cross-gender. The analysis examined the request patterns of Yemeni Arabic speakers related to six situations. It was found that the directness was realized by means of mood derivable strategy and want statements strategy, conventional indirectness, mostly realized by means of query preparatory. Chang \& Hsu (1998)This study investigates differences in request e-mails written in English by Chinese English learners and native American English speakers The results show that while Chinese English learners treat e-mail communications like either formal letters or telephone conversations, native American English speakers regard e-mail communications as closer to written memos It was also found that although the native American English speakers structure their e-mail request messages in a rather direct sequence, the linguistic forms they employ to express their requests are more indirect In contrast, the Chinese English learners structure their request messages in an indirect sequence, but the linguistic forms they use to realize their requests are more direct. (Salvesen) This study focuses on the politeness strategies that are found in requests made by Norwegian speakers and native speakers of English. However, a slight difference was found between the Norwegian speakers of English and the native speakers of English in the request strategies applied to make a request towards a friend. The data showed that the English speakers use more indirect strategies and hints when the Norwegians tend to use an explicit form of request strategies. The researcher found that using a more indirect form of request will lower the face threat. An indirect request will seem politer than an explicit request.

Youssef (2012) in his study investigates the similarities and differences in request strategies employed by Libyan and Malay postgraduate students at USM. The findings give new insights to the directness and requesting behaviours within Libyan and Malaysian students and the challenges of cross-linguistic and cross-cultural communication. Jalilifar (2009) and Razak et al (2018) investigated the request strategies as used by Iranian learners of English as a foreign language and Australian native speakers of English. The result of the study that there is pragmatic development, particularly in the movement from direct to conventionally indirect strategies on the part of EFL learners, the learners who have higher proficiency in English use indirect strategies more than other strategies, whereas native speakers of English balance between these strategies. The learners who have lower proficiency in English use direct strategies more than other strategies. This topic nowadays came to the fore as field of speech acts, so that there is an explosion of researchers and studies done in this field, we can see that this type of speech acts exists in all cultures and societies, every culture has its specific ways of politeness strategies in request.

\section{Theoretical Frame of the Study}

This research adopts (Watts, 2003) concepts of linguistic politeness as understood by ritualized, formulaic utterances, and semi formulaic. According to Watts, formulaic utterances are linguistic norms or expression used in ritualized forms of the verbal interaction which comprise forms of expressions, address commonly used in special speech acts. like apologizing, thanking, or ritualized, and refusing expressions of leave-taking. On the other hand, semi-formulaic expressions are conventionalized forms that hold indirect speech acts suitable to the polite behaviour of a social 
INTERNATIONAL JOURNAL OF ACADEMIC RESEARCH IN BUSINESS AND SOCIAL SCIENCES Vol. 10, No. 6, June, 2020, E-ISSN: 2222-6990 @ 2020 HRMARS

situation. he stated that ritualized, formulaic utterances and semi-formulaic utterances are part of the polite behaviour of distinct forms of linguistic practices. He stated that "when these strategies are absent, their missing is easily interpretable as impoliteness, and when they exist in these situations, they are easily interpretable as politeness".

\section{Conceptual Framework}

The following diagram summarizes the conceptual framework of the study. As seen in the figure below, both Arab and Malay participants employ politeness strategies to achieve successful communication. The Arab and Malay participants belong to two unfamiliar cultures with a different educational background, which presumes that they will employ different politeness strategies.

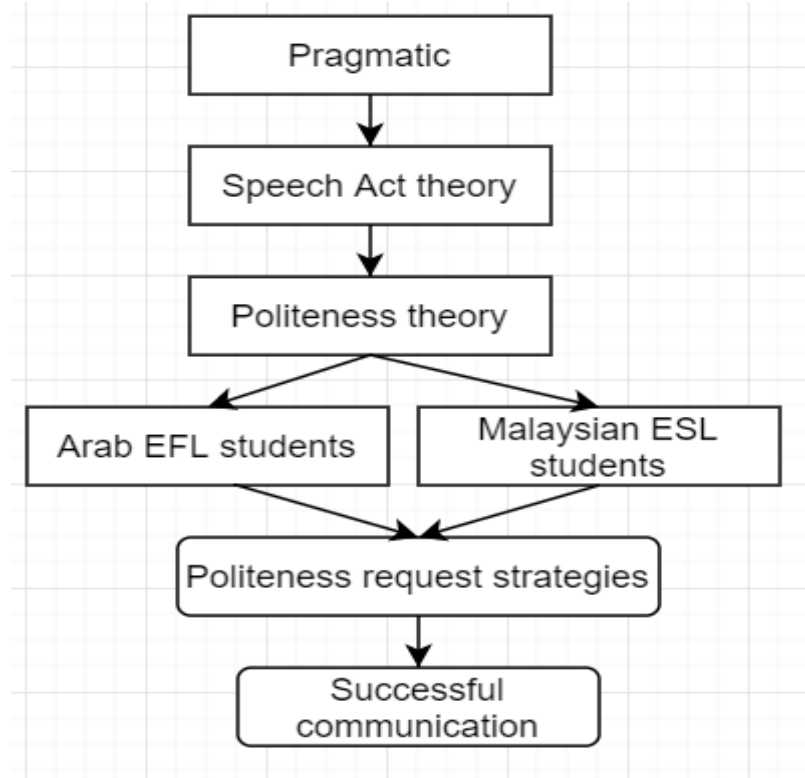

Figure 1 Conceptual framework of the study

\section{Methodology}

This current study adopted quantitative research design. The participants of the study were 6 postgraduate students in one Malasiyan public university. The participants age range 23-27 years old and according to Gordon and Ervin-Tripp (1984), in this age students have acquired request strategies. The data is collected through a discourse situations as this method proved its effectiveness (Tawalbeh \& Al-Oqaily, 2012). The data of the study were collected through interviews with the participants and give them six hypothesized situations and they had to make request regarding these situations which has been adapted from (Alfattah \& Ravindranath, 2009). The participants wrote their requests in paper sheets and then they were analysed based on the theoretical framework of Blum-Kulka et al. (1989) which divides request strategies into direct, conventionally indirect and nonconventionally indirect strategies. the interview happened in the library of the National University of Malaysia. The interview took a length of 40 minutes. 
INTERNATIONAL JOURNAL OF ACADEMIC RESEARCH IN BUSINESS AND SOCIAL SCIENCES Vol. 10, No. 6, June, 2020, E-ISSN: 2222-6990 @ 2020 HRMARS

\section{Discussion and Analysis of Results}

The results will be presented in tables and charts, the percentage and frequency of the strategies types occurred among situations. In these sections, I will analyse the data and present the findings in terms of politeness strategies in the request.

Situation one: in this situation, we have Malay guy asks his friend for help for his applying to Ph.D. in one university and he needs somebody to publish a paper to some journal for him to make his application secure .and he doesn't have time because he's working in management.

From the interview, the politeness strategies he used in the request is (hints) because he didn't request directly.

Situation two: an Arabic guy asks Malay person to help in his health problem he has to go through surgery and he has a problem in his bank account and he can't withdraw money and he must go through the surgery because already he has an appointment with the hospital and requests from his friend to open his bank account to him to withdraw money. The politeness strategy he used is (want statement) he was strongly direct in his request.

Situation three: Arabic guy talking to his Malay friend that he wants to marry Malay girls and he wants him to advice and suggests some Malay girls for him, but at the end of the interview we got that he wants to marry his friend sibling, so he kept beating around the bush to make his Malay friend understand that, then the strategy he used is (hints) because he requested indirectly.

Situation four: in this situation, we have two classmates, the Arabic guy requests from his Malay friend to borrow him his car to go on holiday with his family. The politeness strategy he used was (want statement) because he requested immediately.

Situation five: in this situation, we have two classmates the Malay one asks his Arabic friend a big request where his friend will come from another country and he ask his Arabic friend to let her stay with her. The strategy he used to request from her was (hedged performative). Which means he requested indirectly.

Situation six: two friends talking about financial problems with the Malay guy so he asking his Arabic friend to lend him money because the due time for his rental apartment is in two days. The strategy he used is (query performativity) because he indirectly asked her.

Before I show the tables that present the results, I will provide the table that identifies the politeness strategies and how we conclude the strategy from the data:

\begin{tabular}{|l|l|}
\hline DESCRIPTIVE CATEGORY & EXAMPLE \\
\hline 1. Mood derivable & Give me your lecture notes \\
\hline 2. Performative & I'm asking you to give me your lecture notes \\
\hline 3. Hedged performative & $\begin{array}{l}\text { I would like to ask you to give me ur lecture } \\
\text { notes }\end{array}$ \\
\hline 4. Obligation statement & You will have to give me.... \\
\hline 5. Want statement & I would like you to give me your.... \\
\hline 6. Suggestion formulae & How about giving me your... \\
\hline 7. Query preparatory & \begin{tabular}{l} 
Could you give me your....? \\
\hline 8. hints
\end{tabular} \\
\hline & $\begin{array}{l}\text { I didn't take my lecture notes, I don't want to } \\
\text { take bad marks. }\end{array}$ \\
\hline
\end{tabular}

Table 1 descriptive category 
INTERNATIONAL JOURNAL OF ACADEMIC RESEARCH IN BUSINESS AND SOCIAL SCIENCES Vol. 10, No. 6, June, 2020, E-ISSN: 2222-6990 @ 2020 HRMARS

\section{The Result of the Study}

\begin{tabular}{|c|c|c|c|c|c|c|c|c|}
\hline \multirow[t]{2}{*}{ Situations } & \multicolumn{4}{|c|}{$\begin{array}{r}\text { Direct } \\
\text { strategi } \\
\text { es }\end{array}$} & \multicolumn{2}{|l|}{$\begin{array}{l}\text { onally } \\
\text { Indirect }\end{array}$} & \multirow[b]{2}{*}{$\begin{array}{r}\text { Quer } \\
\text { y } \\
\text { Prep. }\end{array}$} & \multirow[b]{2}{*}{$\begin{array}{r}\text { Hint } \\
s\end{array}$} \\
\hline & $\begin{array}{r}\text { Mood } \\
\text { Derivabl } \\
\mathrm{e}\end{array}$ & $\begin{array}{r}\text { Want } \\
\text { Stateme } \\
\text { nt }\end{array}$ & $\begin{array}{r}\text { perform } \\
\text { ative }\end{array}$ & $\begin{array}{r}\text { obligati } \\
\text { on }\end{array}$ & Suggestion & $\begin{array}{r}\text { Hedge } \\
d \\
\text { Perf.... }\end{array}$ & & \\
\hline Situ 1 & & & & & & & & 1 \\
\hline Situ2 & & 1 & & & & & & \\
\hline Situ3 & & & & & & & & 1 \\
\hline Situ4 & & 1 & & & & & & \\
\hline Situ5 & & & & & & 1 & & \\
\hline Situ6 & & & & & & & 1 & \\
\hline
\end{tabular}

Table 2 . The results of the study

This table shows the results of the situations as the designed given by Blum-Kulka, we can see that the numbers with red colour refer to the strategies employed by Malay respondents and the numbers with blue colour refer to the strategies employed by Arabic respondents, therefore, we see that most of the strategies employed by both of the respondents from two culture use different strategies with a little bit of similarity buying the indirect strategies, then we can look at the similarity and differences from two points of view:

\section{Directness Scale}

this scale is given by Blum-kulk to measure the range of directness in the strategies employed by responden

\begin{tabular}{|r|r|}
\hline Strategy type & Direct \\
\hline Mood derivable & \\
\hline Per formative & \\
\hline Obligation statement & \\
\hline Suggestion statement & \\
\hline Want statement & \\
\hline Hedged performative & \\
\hline Hints & Indirect \\
\hline Query preparatory & \\
\hline
\end{tabular}

Table 3. Directness Scale 
The request patterns considered as the most direct are the ones in which requestee force is marked by syntactically way, or indicated explicitly. As the rules are given by Spencer Blum-kulk we can conclude that there is a significant difference between Arabs and Malay people in the politeness strategy employed in the request, $65 \%$ from the strategies used by Arabic people considered direct (want a statement, want statement, hints) while the strategies used by Malay people can be considered $100 \%$ indirect (hints, query preparatory, hedged performative,).

Malay people tend to use an explicit form of request strategies. According to Brown and Levinson, mentioned in (Salvesen) using a more indirect form of request will lower the face threat. An indirect request will seem more polite than an explicit request.

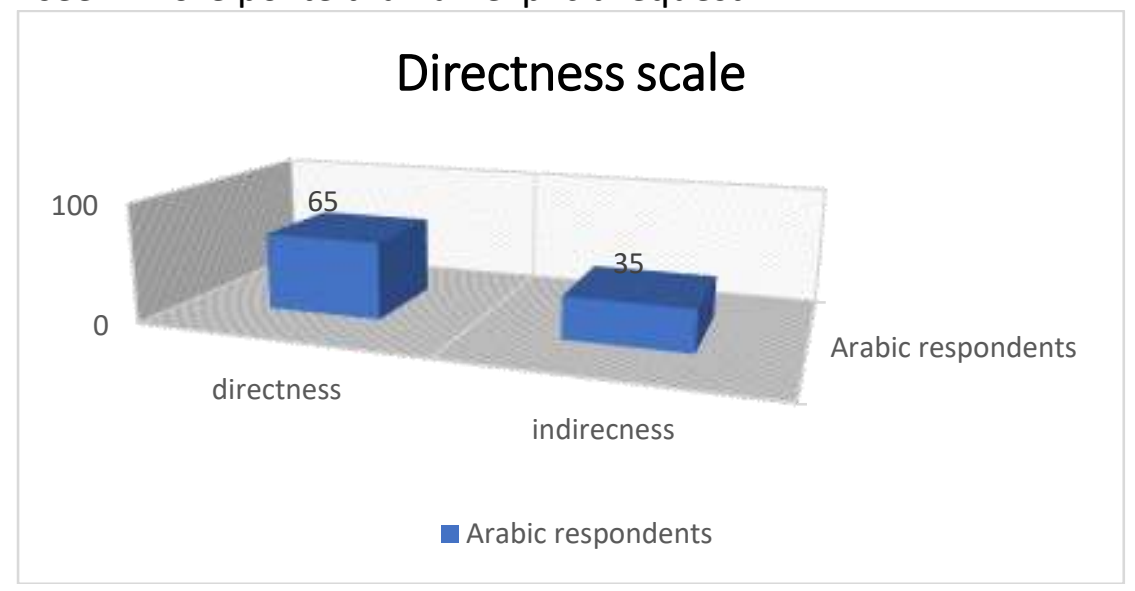

Figure2 Directness scale

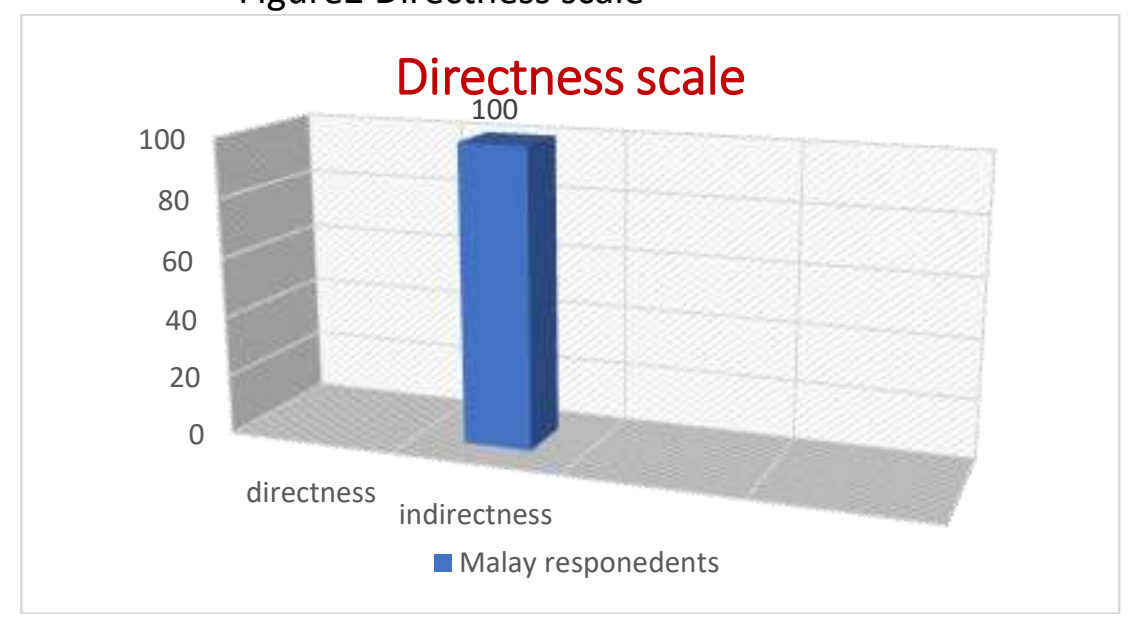

Figure 3 Directness scale

\section{Politeness Scale}

This scale also is given by Blum-kulk to enable us to measure how much the strategies are polite, so that he arranged them in this table like this: from top to down as the politest to the least polite, it's clear that the indirect strategies are the most polite as the table. 
INTERNATIONAL JOURNAL OF ACADEMIC RESEARCH IN BUSINESS AND SOCIAL SCIENCES Vol. 10, No. 6, June, 2020, E-ISSN: 2222-6990 @ 2020 HRMARS

\begin{tabular}{|r|l|}
\hline Strategy type & Most polite \\
\hline Query preparatory & \\
\hline Hedged performative & \\
\hline Suggestion formula & \\
\hline Hints & \\
\hline Want statement & \\
\hline Mood derivable & \\
\hline Performative & \\
\hline Obligation statement & Least polite \\
\hline & \\
\hline
\end{tabular}

Table 4 politeness scale

There is a slight difference between Arabs and Malay participants using politeness strategies as listed in this table. we can see that the strategies employed by Malay participants (hints, hedged performative, query preparatory) are politer than those employed by Arabic participants (hints, want a statement, want statements) because of the more indirect strategies the more politeness.

Polite behaviour and polite language need to be taught. we are not born with politeness, but rather it is learned in social contexts.

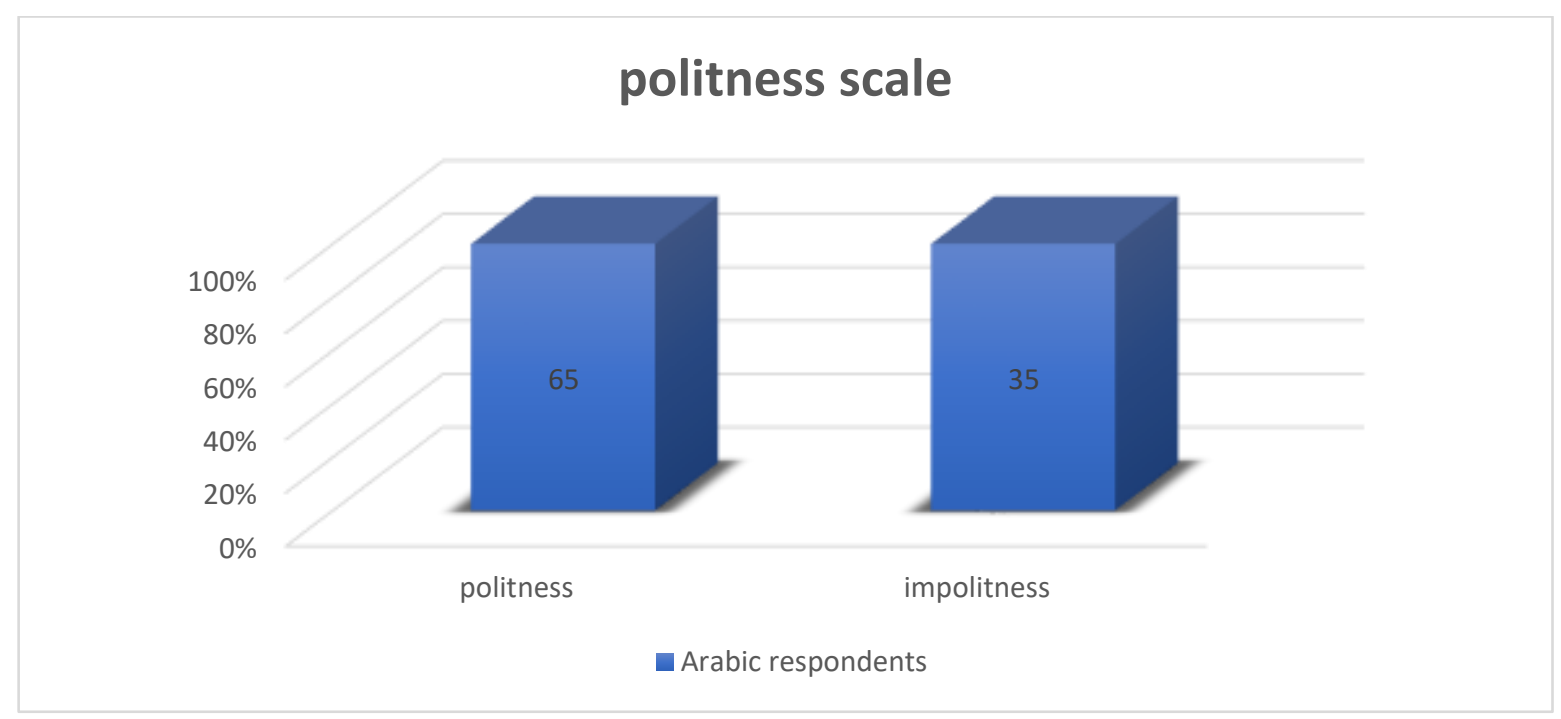

Figure 4 politeness scale 
INTERNATIONAL JOURNAL OF ACADEMIC RESEARCH IN BUSINESS AND SOCIAL SCIENCES

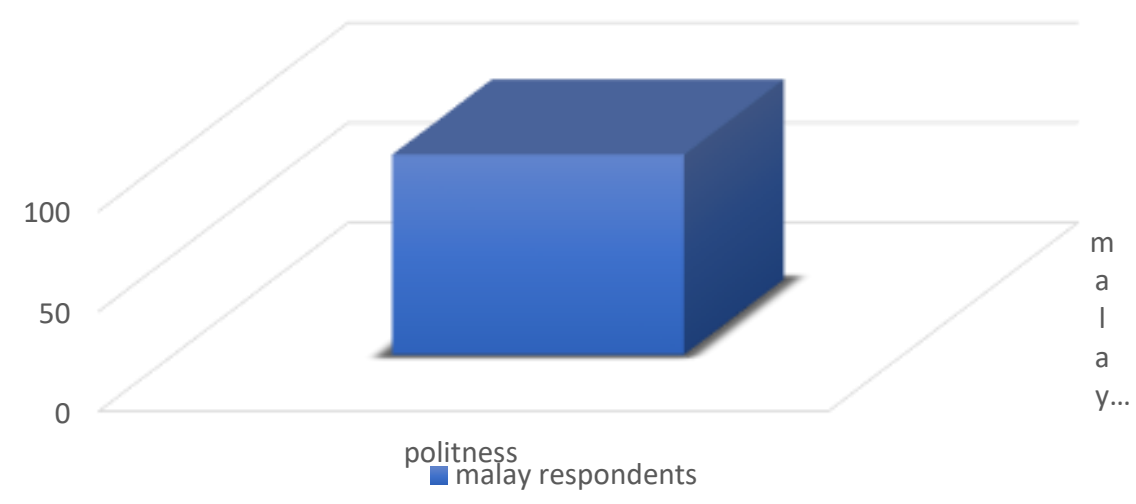

Figure 5 politeness scale

\section{Conclusion}

The aim of this study was to investigate the politeness strategies in making request used by by Arab EFL and Malaysian ESL students. Also, the study has

investigated the similarities and differences in request strategies employed by Malay and Arabic people. In findings of the study showed a slight difference between Malaysian ESL and Arab EFL students in th use of request strategies. The findings showed that Malaysian respondents used more indirect strategies (hints, query preparatory, hedged performative) while Arabs respondents tend to use an explicit form and direction of request strategies (want statements, hints). The findings of the study gave a new perspective on the strategies of requesting behaviours within Arabs and Malaysian and the challenges of and cross-cultural communication cross-linguistic.. The number of the participants is limited to six participants, enlarging the number of participants with the number with the hypothesized situations would give more explicit and authentic results. Future research can fill the gap by focusing on both politeness and impoliteness strategies.

The study contributes to the body of knowledge related to pragmatic and the theory of speech act and their understanding and practices surrounding sociolinguistic. The current study will add to existing research and literature in the area of sociolinguistic. Findings of the study will inform students, lecturers and academic staff that intermingle with international students about the politeness strategies used by Arab EFL students to avoid misunderstanding and for effective communication.

\section{References}

Al-Marrani, Y. M. A., \& Sazalie, A. B. (2010). Polite request strategies by Yemeni females: A sociopragmatic study. Modern Journal of Applied Linguistics, 2(6), 478-516.

Al-Qahtani, H. A. (2009). Female use of politeness strategies in the speech act of offering: A contrastive study between spoken Saudi Arabic and spoken British English. King Saud University.

Al-Qahtani, H. A. (2009). Female use of politeness strategies in the speech act of offering: A contrastive study between spoken Saudi Arabic and spoken British English. Retrived from http://www. academia. edu/2020368. 
INTERNATIONAL JOURNAL OF ACADEMIC RESEARCH IN BUSINESS AND SOCIAL SCIENCES Vol. 10, No. 6, June, 2020, E-ISSN: 2222-6990 @ 2020 HRMARS

Al-Shboul, Y., Maros, M., \& Yasin, M. S. M. (2012). An intercultural study of refusal strategies in English between Jordanian EFL and Malay ESL postgraduate students. 3L: Language, Linguistics, Literature $^{\circledR}, 18(3)$.

Atawneh, A. M. A. H. (1991). Politeness Theory and the directive speech act in Arabic-English Bilinguals: An empirical study (Doctoral dissertation, State University of New York at Stony Brook).

Aspinall, P., Hashem, F., \& Song, M. (2011). ESRC. Austin, JL (1962) How to Do Things with Words, Oxford: Clarendon Press. Back, L.(2007) The Art of Listening, Oxford and New York:

Baraitser, B. L. (2008) Maternal Encounters: The Ethics of Interruption, London: Routledge. Displaying Families: A New Concept for the Sociology of Family Life, 39(855), 206.

Chang, Y. Y., \& Hsu, Y. P. (1998). Requests on e-mail: A cross-cultural comparison. RELC journal, 29(2), 121-151.

Brown, P. (1978). Levinson. Politeness. Some Universals in Language Use, 1987.

Chang, Y.-Y., \& Hsu, Y.-P. (1998). Requests on e-mail: A cross-cultural comparison. RELC Journal, 29(2), 121-151.

Damen, L. (1987). Culture learning: The fifth dimension in the language classroom (Vol. 11478): Addison Wesley Publishing Company.

Damen, L., \& Savignon, S. J. (1987). Culture learning: The fifth dimension in the language classroom (Vol. 11478). Reading, MA: Addison-Wesley Publishing Company.

Dittrich, W. H., Johansen, T., \& Kulinskaya, E. (2011). Norms and situational rules of address in English and Norwegian speakers. Journal of Pragmatics, 43(15), 3807-3821.

Jalilifar, A. (2009). Request Strategies: Cross-Sectional Study of Iranian EFL Learners and Australian Native Speakers. English language teaching, 2(1), 46-61.

Salvesen, K. E. (2015). Politeness strategies in requests by Norwegian learners of English in comparison with native English speakers. Hawaii Pacific University TESOL Working Paper Series, 13, 53-69.

Razak, N. A., Alakrash, H., \& Sahboun, Y. (2018). English Language Teachers' readiness For the Application of Technology Towards Fourth Industrial Revolution Demands. Asia-Pacific Journal of Information Technology and Multimedia, 7(2-2), 89-98.

Tawalbeh, A., \& Al-Oqaily, E. (2012). In-directness and politeness in American English and Saudi Arabic requests: A cross-cultural comparison. Asian Social Science, 8(10), 85.

Umar, A., \& Majeed, A.-T. (2006). The speech act of complaint as realized by advanced Sudanese learners of English. Journal of Educational \& Social Sciences \& Humanities, 18(2), 8-40.

Watts, R. J. (2003). Politeness. Cambridge University Press.

Youssef, A. M. S. (2012). Study of request strategies employed by Libyan and Malay postgraduate students at USM. International Journal of Learning and Development, 2(2), 144-151. 